\title{
Organizational Structure and
}

\section{Innovation in Academic Libraries}

\begin{abstract}
A study was conducted in four university libraries to assess Hage and Aiken's theory that the relationship between the structural variable complexity and rate of innovation is positive and that it is negative for centralization, formalization, and stratification. On the whole, the findings support the theory. The methodology, with some modifications, was shown to be transferable.
\end{abstract}

\section{INTRODUCTION}

We live in an organizational society that is becoming increasingly complex. ${ }^{1}$ Most of our activities are carried out in the context of one or more organizations. These organizations exist for a purpose and can be viewed as vehicles for accomplishing goals and objectives.

Although the study of organizations dates back to the nineteenth century and the literature is voluminous, as yet there is no cohesive body of organizational theory in the sense of a set of empirically verified propositions that are logically linked. Rather there are a number of conceptualizations or perspectives that are becoming increasingly crystallized, based on empirical research. ${ }^{2}$

The field of organizational theory has various constructs that can be used in studying organizations. One of the most enduring is the ideal-type bureaucratic model described by Max Weber. ${ }^{3}$ Characteristics of this model include a hierarchy of authority, division of labor, rules and regulations, hiring and promotion on the basis of technical competence, impersonality of interpersonal relations, and a system of discipline and control. The literature on bureaucracy is extensive and includes many criticisms of the model, including its deleterious effect on the ability to innovate. ${ }^{4}$

This paper reports on a study of the relationship between the organizational structural variables of complexity, centralization, formalization, and stratification and the rate

Helen A. Howard is associate professor, Faculty of Library Science, University of Toronto, Ontario, Canada. of innovation in four university libraries. ${ }^{5}$ The framework for the study is derived from the work of Jerald Hage and Michael Aiken. ${ }^{6}$ The purpose of the study is twofold: (1) to assess in a selection of university libraries the transferability of portions of the theory and methodology dealing with structural variables developed by Hage and Aiken; and (2) to determine whether the theory and methodology are viable research tools that can provide library administrators with increased insights into the organizational dynamics of their institutions.

\section{THEORETICAL AND \\ METHODOLOGICAL BACKGROUND}

Between 1968 and 1974 Hage and Aiken and their students in sociology at the University of Wisconsin published a series of studies exploring a number of organizational relationships in sixteen health and social welfare agencies in the midwestern United States. The book, Social Change in Complex Organizations, brings together the results of a great deal of their research and of others working in related areas. ${ }^{7}$ They present hypotheses relating seven variables to the rate of program change in organizations. Four of the independent variables are of the structural type-complexity, centralization, formalization, and stratification; three are of the performance type-production, efficiency, and job satisfaction. A review of their work shows that the label for the dependent variable has been evolving: at first they called it adaptability, then rate of program change, and finally rate of innovation. This 
last terminology is used in this paper.

The four hypotheses involving structural variables postulated by Hage and Aiken are:

1. The greater the complexity, the greater the rate of innovation.

2. The higher the centralization, the lower the rate of innovation.

3 . The greater the formalization, the lower the rate of innovation.

4. The greater the stratification, the lower the rate of innovation.

One of the major theoretical underpinnings is Hage's structural-functional theory, "An Axiomatic Theory of Organizations." However, in developing their research design they incorporated many of the conceptualizations and research of others including Richard Hall, ${ }^{9}$ Peter Blau, ${ }^{10}$ Tannenbaum and Backman, ${ }^{11}$ D. S. Pugh and his associates, ${ }^{12}$ and Burns and Stalker. ${ }^{13}$

A major theme in Hage and Aiken's research is that it is important to study organizations from a sociological rather than a psychological viewpoint. The essence of this view is that "sociological properties are more than a summation of psychological properties."14 Their research design centered around a three-wave longitudinal panel study in which data were collected in 1964, 1967 , and 1970 from sixteen health and social welfare agencies in the midwestern United States. They interviewed 520 persons, including all directors and department heads and a stratified random sample of other staff. Separate interview schedules using predominately forced-choice questions were used for executive directors, department heads, and staff, respectively. Standard regression techniques were used to analyze the data. The unit of analysis was the organization.

The concept of "social position" is a key concept in the Hage and Aiken method for taking a sample and aggregating scores for the variables being studied. A social position can be described as the job at the intersection of a particular level in a hierarchy and a particular occupational specialty. Social positions can be thought of as a matrix as shown in figure 1 . In this example there are sixteen positions involving twenty-eight individuals.

Using the social position method, data were aggregated to obtain an organizational score in two steps: (1) by calculating the mean of each index for each variable for each social position; and (2) calculating an average of the means obtained in step one. The intent of computing a mean for social positions is to minimize distortions due to differences in individual perceptions. The objective is to determine what is inherent in the position rather than the individual(s) filling it. The aggregated figure represents the organizational score.

\section{LibraRy StUdy BACKGround}

University libraries are a type of professional work organization. At the same time they are service organizations, that is, ones "whose prime beneficiary is the part of the public in direct contact with the organization, with whom and on whom members work - in short an organization to serve clients." 15 The litany of their problems continues in the literature of librarianship. "The

Director

(level 1)

Associate Director (level 2)

Department Head (level 3)

Senior Librarian

(level 4)

Librarians

(level 5)

\begin{tabular}{ccccccc}
$\mathrm{X}$ & & & & & & $\begin{array}{c}\text { Total } \\
\text { Social } \\
\text { Positions }\end{array}$ \\
$\mathrm{X}$ & $\mathrm{X}$ & $\mathrm{X}$ & $\mathrm{X}$ & $\mathrm{X}$ & $\mathrm{X}$ & 1 \\
& $\mathrm{X}$ & $\mathrm{XX}$ & $\mathrm{X}$ & & $\mathrm{XX}$ & 1 \\
$\begin{array}{c}\text { Adminis- } \\
\text { tration }\end{array}$ & $\mathrm{XXXX}$ & $\mathrm{XXXXX}$ & $\mathrm{XX}$ & $\mathrm{X}$ & $\mathrm{XXX}$ & 4 \\
\hline
\end{tabular}

OCCUPATIONAL SPECIALTY

Fig. 1

Example of Library Social Positions 
Changing Role of Directors of University Libraries" by McAnally and Downs ${ }^{16}$ and Millicent Abell's recent article ${ }^{17}$ cover the major areas of difficulty.

There is widespread agreement among organizational theorists and researchers that, for organizations to survive and be viable with a distinct role to play, they need to be flexible and able to meet the challenges of a changing environment. Drucker has stated that:

Modern organizations must be capable of change. Indeed it [sic] must be capable of initiating change, that is, innovation. It must be able to move scarce and expensive resources of knowledge from areas of low productivity and non-results to opportunities for achievement and contribution. ${ }^{18}$

More recently he has added:

And in turbulent times, the first task of management is to make sure of the institution's capacity for survival, to make sure of its structural strength and soundness, of its capacity to survive a blow, to adapt to sudden change, and to avail itself of new opportunities. ${ }^{10}$

However, innovation itself may not always be a "good" thing. Decision makers must weigh the potential benefits of implementing an innovation at any given point in time against such considerations as possible disruptions in service, the dropping of some programs in order to implement others, the effect on staff morale, and the adjustment needed by users and staff to accept an innovation.

University libraries, like others, are faced with the need to be flexible and to be able to meet the challenges of a turbulent environment. However, little research has been done on libraries as organizations. Library administrators need theory supported by empirical data to assist them in developing effective organizational structures. Prior to the study reported in this paper, Hage and Aiken's theory and methodology had not been evaluated in any type of library. They observed that their variables are general ones and therefore can be applied to any organization. ${ }^{20}$ It seems useful to apply them to libraries.

\section{Research Design}

The population of this exploratory study consisted of the university library members of the Association of Research Libraries. Four libraries in the northeastern United States were selected as a purposive sample. The intent was to select two pairs of libraries so that within each pair there would be (1) an apparent difference in the rate of innovation, and (2) a similarity in the size of the full-time equivalent staff and operating expenditures. Judgment of the first characteristic was, of necessity, very subjective. It was based on observation, press reports, and/or personal accounts. The staffing and expenditures for the four libraries are shown in table $1 .{ }^{21}$

The method followed as closely as possible that used by Hage and Aiken. The four hypotheses relating complexity positively and centralization, formalization, and stratification negatively to the rate of innovation provided the vehicle for assessing the theory and method.

In some instances circumstances dictated a modification in the method. For example, the library study is cross-sectional rather than longitudinal and thus examines characteristics of the libraries at one point. An $N$ of four was dictated by the level of resources available and the amount of data one researcher can handle. Random sampling was used to

TABLE 1

StafF and Expenditures of the Libraries Studied*

\begin{tabular}{|c|c|c|c|c|}
\hline Characteristic & Library A & Library B & Library C & Library D \\
\hline $\begin{array}{l}\text { Staff (FTE 1974-75) } \\
\text { Professional } \\
\text { Technical and clerical } \\
\text { Student assistants }\end{array}$ & $\begin{array}{r}94 \\
246 \\
40 \\
380\end{array}$ & $\begin{array}{r}92 \\
177 \\
43 \\
312\end{array}$ & $\begin{array}{r}35.5 \\
37.5 \\
41.0 \\
114.0\end{array}$ & $\begin{array}{r}54.6 \\
85.3 \\
66.1 \\
206.0\end{array}$ \\
\hline $\begin{array}{l}\text { Expenditures } \\
1974-75 \\
1973-74 \\
1972-73\end{array}$ & $\begin{array}{r}\$ 4,921,530 \\
4,312,593 \\
3,777,626\end{array}$ & $\begin{array}{r}\$ 5,610,976 \\
4,935,083 \\
4,274,606\end{array}$ & $\begin{array}{r}\$ 1,919,043 \\
1,618,347 \\
1,862,578\end{array}$ & $\begin{array}{r}\$ 2,223,442 \\
1,991,457 \\
1,980,419\end{array}$ \\
\hline
\end{tabular}

'Data were taken initially from ARL's statistics for 1973-74 but were updated during data collection. 
draw the sample but did not include support staff since they display little commonality from one library to another. Three strata of staff were delineated: directors, senior staff including department heads, and other professional staff.

Data collection instruments were designed to be used as questionnaires or as interview schedules. All directors were interviewed as were approximately 20 percent of the total sample. Site visits were scheduled so that interviewing and the completion of questionnaires were carried out simultaneously. From the 147 subjects selected, 139 usable responses were obtained. Details of the distribution of respondents and usable responses are shown in table 2.

The variables, indicators, and measures are shown in table 3.
Theoretical and operational definitions are provided in the following section.

\section{DEFINITIONS}

Definitions for "organization" abound and tend to reflect the originator's particular perspective. The one selected for use in this study was presented by Hall:

An organization is a collectivity with a relatively identifiable boundary, a normative order, authority ranks, communications systems and membership coordinating systems; this collectivity exists on a relatively continuous basis in an environment and engages in activities that are usually related to a goal or a set of goals. ${ }^{22}$

The term "professional" includes librarians and specialists who meet the requirements set forth in the American Library Association's 1976 statement, Library Education

TABLE 2

Detalls of Respondents and Usable Responses

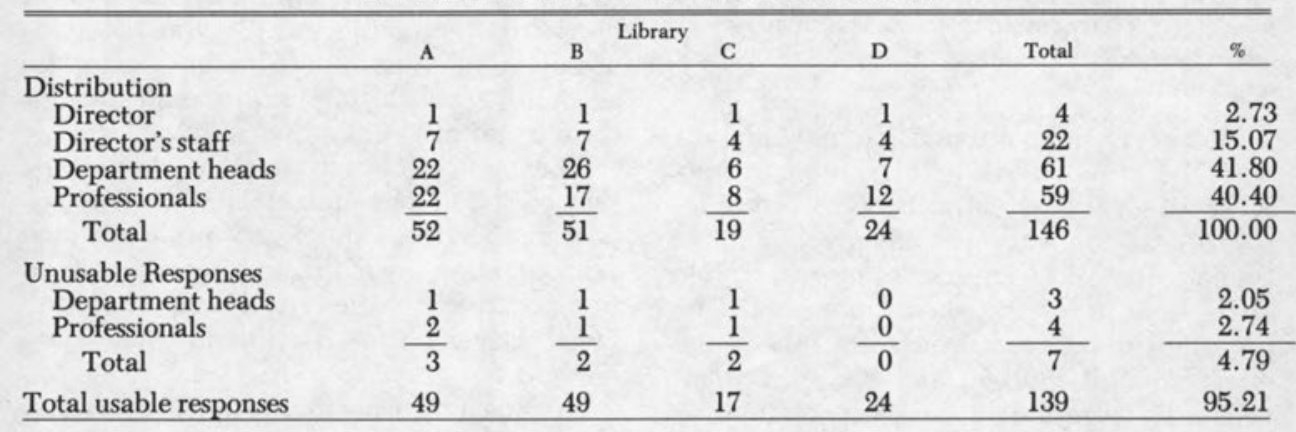

TABLE 3

Variables, Indicators, Measures

\begin{tabular}{ll}
\hline Variable & \multicolumn{1}{c}{ Indicator } \\
\hline Complexity & $\begin{array}{l}\text { Number of occupational specialties } \\
\text { Level of training }\end{array}$
\end{tabular}

Centralization Proportion of jobs that participate in decision making

Number of areas in which decisions are made

Formalization Proportion of jobs that are codified Range of variation allowed within jobs

Stratification

Difference in income among jobs

Proportion of lower participants

Innovation

Annual rate of innovation
Number of occupational specialties

Index of professional training

Index of professional activity

Index of participation in decision making (strategic)

Index of hierarchy of authority, i.e., job autonomy

Index of job codification

Index of rule observation

Rule manual

Job descriptions

Index of job specificity

Ratio of average department head income to average professional income

Percentage of total respondents who are professionals

Mean annual rate of implementation of significant new ideas, services, products, processes, changes in organizational structure, and/or staffing 
and Personnel Utilization. ${ }^{23}$

"Complexity" refers to the level of knowledge and expertise in an organization. There are two complementary aspects of complexity: the number of occupational specialties and the degree of professionalism of each. ${ }^{24}$ Three measures of complexity were used: (1) the number of distinct occupational specialties; (2) an index of professional training; and (3) an index of professional activity. In order to determine occupational specialties, respondents were asked if there was any special kind of talent or knowledge that they used frequently in their work. If the answer was yes, they were then asked to describe the specialty or specialties. In addition, all respondents were asked to provide their job title and their main duties.

The professional training index was obtained by aggregating weighted values assigned for different levels of education. The index for professional activity consisted of counting up the number of memberships in professional organizations, the number of meetings attended, papers presented, and offices held in the previous three and one-half years.

"Centralization" refers to the degree to which library professional staff participate in decision making. It has two indicators: (1) an index of participation, which measures input to decisions that affect the organization as a whole; and (2) an index of hierarchy of authority, which measures respondents' degree of control over their immediate work environment; that is, how much action can be taken regarding work without referring the matter to a supervisor.

"Formalization" indicates the degree of work standardization and the amount of deviation that is allowed from standards. This definition is operationalized in five ways. There are two aspects of the use of rules as a control mechanism. One is the number of regulations specifying who is to do what, where, and when. Another is the diligency in enforcing these rules. The former is called the index of codification and the latter the index of rule observation. The score is obtained from six forced-choice questions. The three other indexes, which complete the measures for formalization, are based on questions that indicate: (1) the presence or absence of a rules manual; (2) the existence of a written job de- scription for the respondent's job; and (3) an index of job specificity that is derived from answers to six statements, such as "Everyone has a specific job to do."

"Stratification" refers to the way in which rewards are distributed to the jobs in an organization. Two measures are used: (1) income ratio, which is the ratio between professional and department head income; and (2) proportion of lower participants, which is the ratio of nonsupervisors interviewed to the total number of people interviewed.

Many definitions of "innovation" exist. The definition used in this study is "the generation, acceptance, and implementation of new ideas, processes, products or services" for the first time within an organizational setting. ${ }^{25}$ This definition that was first used by Victor Thompson, ${ }^{26}$ denotes a concern only for innovations that have been successfully incorporated into an organization's structure, although they might conceivably be discontinued at some later point. Pierce and Delbecq, when presenting their support for this definition, point out that it recognizes the fact that the process of incorporating something new within an organization can represent a strategic effort for the organization, regardless of whether other organizations have already proceeded through the process. ${ }^{27}$

To obtain information on innovations, the directors and senior staff were asked, "Has your library system [or whatever unit was appropriate] made any changes which have made a noticeable difference to users and/or staff since January 1972?" [a span of three and one-half years]. The question avoids such value-laden terms as "major," "significant," or even "innovation." A battery of follow-up questions probed the nature of the reported changes. Seven criteria were used to determine whether the reported changes were innovations or an expansion or modification of something already in existence: new products and services; amount of change in task content; effect on working relationships and staffing; the number of staff and clients affected; effect on ongoing budget allocations; new performance capacity; expected longevity. The rate of innovation was obtained by taking the mean of the number of innovations in each library for the period January 1972 through June 1975. The innovations were 
TABLE 4

Total InNOvations AND AnNual Rate

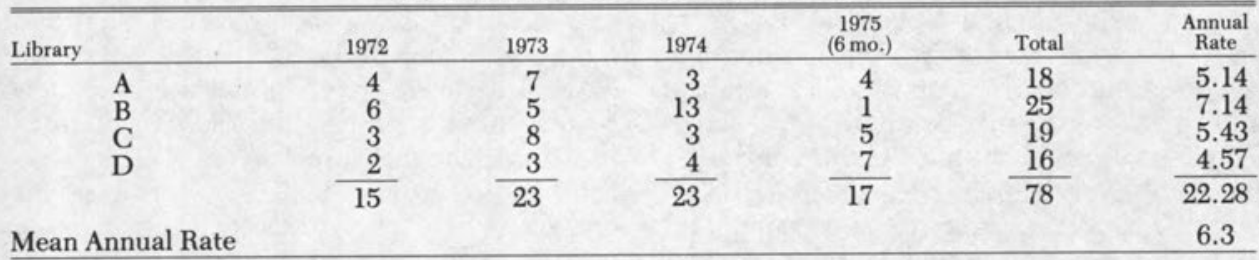

then classified by Knight's four categories: service or product; production process; organizational structure; people innovation. ${ }^{28}$

\section{Assumptions}

It is assumed that Hage and Aiken's extensive work to develop internal consistency, reliability, and content validity for the core indicators and measures warrants acceptance for use in this study. It is also assumed that, although not all of the conceivable structural variables are being studied, the four that are evaluated are important to an organization's rate of innovation. Furthermore, it is assumed that an organization is a system and that a change in one variable in the system leads to change in other variables. This assumption implies that certain organizational configurations are most likely to be associated with a high rate of innovation.

\section{Limitations}

The major limitations of this study are: (1) the fact it is a cross-sectional study and thus limited to a specific time in the life of the selected libraries; (2) the $N$ is limited to four; (3) only descriptive statistics can be used in analyzing the findings; (4) only one type of library was studied; (5) the interpretation of the findings must be done with caution since there is no factual basis for generalizing beyond the four libraries studied.

\section{Findings}

This study has shown that with some modifications Hage and Aiken's methodology for studying the association of complexity, centralization, formalization, and stratification with the rate of innovation can be applied to a selection of university libraries.

Library directors and senior staff reported ninety changes that they deemed to have resulted in a noticeable difference to users and/ or staff. Of this total, seventy-eight were judged to be innovations. Libraries B and C show the highest annual rates of innovation with means of 7.14 and 5.43 , respectively. Table 4 shows the rate of innovation for all four libraries. Table 5 lists the innovations most frequently cited. These data indicate that a great variety of innovations were reported since six reported innovations account for only 27 percent of the total. Table 6 , which records the distribution of innovations according to Knight's classification, shows that thirty out of seventy-eight, or 38 percent, of the innovations fall into the service/ product category.

This investigator took a neutral stand on whether any particular innovation had positive or negative value since there is no reliable evidence of what constitutes a good innovation or when an organization is damaging the society around it by its resistance to implementing an innovation.

Overall the empirical data support the hypotheses more than not. In an attempt to obtain some sense of the relative strengths of the scores for each index, ratios were calculated by dividing the actual score for a measure by the total possible score. These data for each indicator are presented in table 7.

In summary, for libraries A and B the data support hypotheses two, three, and four, but not the first. Findings for libraries $\mathrm{C}$ and $\mathrm{D}$ are mixed: data for the index of professional

TABLE 5

Innovations Most Frequently Cited

\begin{tabular}{|c|c|c|}
\hline Innovation & Frequency & Percent \\
\hline Online shared cataloging & 4 & 5.0 \\
\hline Online database searching & 4 & 5.0 \\
\hline Additional staff officers & 4 & 5.0 \\
\hline $\begin{array}{l}\text { Reorganization of library } \\
\text { system }\end{array}$ & 3 & 4.0 \\
\hline $\begin{array}{l}\text { Electronic security } \\
\text { system }\end{array}$ & 3 & 4.0 \\
\hline $\begin{array}{l}\text { Library instruction } \\
\text { program }\end{array}$ & 3 & 4.0 \\
\hline
\end{tabular}


TABLE 6

Classification of InNovations

\begin{tabular}{|c|c|c|c|c|c|c|c|c|c|c|}
\hline \multirow[b]{2}{*}{$\underline{\text { Library }}$} & \multicolumn{2}{|c|}{$\begin{array}{l}\text { Service or } \\
\text { Product }\end{array}$} & \multicolumn{2}{|c|}{$\begin{array}{c}\text { Production } \\
\text { Process }\end{array}$} & \multicolumn{2}{|c|}{$\begin{array}{c}\text { Organizational } \\
\text { Structure }\end{array}$} & \multicolumn{2}{|c|}{$\begin{array}{c}\text { People } \\
\text { Innovation }\end{array}$} & \multirow{2}{*}{\multicolumn{2}{|c|}{ requency $^{\text {Total }}$}} \\
\hline & Frequency & $\%$ & Frequency & $\%$ & Frequency & $\%$ & Frequency & $\%$ & & \\
\hline $\begin{array}{l}\text { A } \\
\text { B } \\
\text { C } \\
\text { D }\end{array}$ & $\begin{array}{r}5 \\
12 \\
10 \\
3 \\
30\end{array}$ & $\begin{array}{l}27.8 \\
48.0 \\
52.6 \\
18.8\end{array}$ & $\begin{array}{r}4 \\
5 \\
4 \\
4 \\
17\end{array}$ & $\begin{array}{l}22.2 \\
20.0 \\
21.1 \\
25.0\end{array}$ & $\begin{array}{r}8 \\
4 \\
4 \\
5 \\
21\end{array}$ & $\begin{array}{l}44.4 \\
16.0 \\
21.1 \\
31.3\end{array}$ & $\begin{array}{r}1 \\
4 \\
1 \\
4 \\
10\end{array}$ & $\begin{array}{r}4.6 \\
16.0 \\
5.3 \\
25.0\end{array}$ & $\begin{array}{l}18 \\
25 \\
19 \\
16 \\
78\end{array}$ & $\begin{array}{l}23.1 \\
32.1 \\
24.4 \\
20.5 \\
1000\end{array}$ \\
\hline
\end{tabular}

TABLE 7

SCORES FOR VARIABLE INDEXES

\begin{tabular}{|c|c|c|c|c|c|c|c|c|c|}
\hline \multirow{2}{*}{ Variables } & \multirow{2}{*}{ Measures } & \multicolumn{2}{|c|}{ Library A } & \multicolumn{2}{|c|}{ Library B } & \multicolumn{2}{|c|}{ Library C } & \multicolumn{2}{|c|}{ Library D } \\
\hline & & Score & Ratio & Score & Ratio & Score & Ratio & Score & Ratio \\
\hline Complexity & $\begin{array}{l}\text { Number occupational } \\
\text { specialties } \\
\text { Index of professional }\end{array}$ & 32.0 & .44 & 28.0 & .39 & 13.0 & .18 & 19.0 & .26 \\
\hline & $\begin{array}{l}\text { training } \\
\text { Index of professional }\end{array}$ & 8.4 & .60 & 7.2 & .51 & 6.9 & .49 & 6.3 & .45 \\
\hline Centralization & $\begin{array}{l}\text { activity } \\
\text { Index of participation }\end{array}$ & 9.0 & .26 & 7.7 & .23 & 7.9 & .23 & 4.6 & .14 \\
\hline & $\begin{array}{l}\text { in decision making } \\
\text { Index of hierarchy of }\end{array}$ & 49.2 & .56 & 49.4 & .57 & 45.7 & .52 & 37.7 & .43 \\
\hline Formalization & $\begin{array}{l}\text { authority } \\
\text { Index of job codification } \\
\text { Index of rule observation } \\
\text { Rule manual } \\
\text { Job descriptions } \\
\text { Job specificity }\end{array}$ & $\begin{array}{r}10.4 \\
11.3 \\
3.3 \\
5.2 \\
6.8 \\
15.7\end{array}$ & $\begin{array}{l}.17 \\
.56 \\
.41 \\
.44 \\
.68 \\
.65\end{array}$ & $\begin{array}{r}8.6 \\
10.6 \\
2.9 \\
4.7 \\
5.4 \\
16.2\end{array}$ & $\begin{array}{l}.14 \\
.50 \\
.36 \\
.40 \\
.54 \\
.68\end{array}$ & $\begin{array}{r}10.7 \\
9.6 \\
2.7 \\
4.0 \\
5.4 \\
14.4\end{array}$ & $\begin{array}{l}.18 \\
.48 \\
.34 \\
.33 \\
.54 \\
.60\end{array}$ & $\begin{array}{r}9.6 \\
10.1 \\
3.2 \\
3.5 \\
4.2 \\
15.9\end{array}$ & $\begin{array}{l}.16 \\
.50 \\
.40 \\
.29 \\
.42 \\
.66\end{array}$ \\
\hline Stratification & $\begin{array}{l}\text { Income ratio } \\
\text { Proportion of lower }\end{array}$ & 1.4 & .93 & 1.1 & .75 & 1.3 & .87 & 1.5 & 1.00 \\
\hline Innovations & $\begin{array}{l}\text { participants } \\
\text { Annual rate of }\end{array}$ & 45.0 & .83 & 33.3 & .62 & 42.1 & .78 & 54.2 & 1.00 \\
\hline & innovations & 5.1 & .72 & 7.1 & 1.00 & 5.4 & .76 & 4.6 & .64 \\
\hline
\end{tabular}


activity support hypothesis one, but the index of occupational specialties does not. Hypothesis two is supported by the data for the index of participation in decision making, but not by the index of hierarchy of authority. The hypothesis regarding formalization is supported by the index of job codification, rule observation, and job specificity, but not for the rule manual and job descriptions. The fourth hypothesis is supported by both indicators used. Details of the findings follow.

Hypothesis 1: The greater the complexity, the greater the rate of innovation.

The three indexes for complexity, i.e., number of occupational specialties, professional training, and professional activity, all have higher values in library A than in library B. Thus the data do not support the hypothesis. Library C has fewer occupational specialties than library $\mathrm{D}$, but its scores for professional training and activity are higher as is its rate of innovation. The data support the hypotheses for two out of three indicators.

Hypothesis 2: The higher the centralization, the lower the rate of innovation.

A high score in participation and a low score in hierarchy of authority indicate low centralization. Library B has a higher score than library A for participation in decision making and a lower score for hierarchy of authority. Therefore, the data support the hypothesis. Library C has a considerably higher score for the index of participation than library D, but its score for the index of hierarchy of authority is also higher. Thus the data for the first indicator support the hypothesis but not for the second.

Hypothesis 3: The greater the formalization, the lower the rate of innovation.

The variable formalization is measured by five indexes: index of job codification, index of rule observation, rule manual, job descriptions, and job specificity. High scores in all but job codification indicate a high degree of formalization. The data show that library A has higher scores than library B for all the measures except job specificity. T'he hypothesis is therefore supported by three out of five of the indicators, the exceptions being job codification, but not for rule manual and job descriptions.

Hypothesis 4: The greater the stratification, the lower the rate of innovation.
In both pairs of libraries the results are consistent. The scores for income ratio and proportion of lower participants are higher in libraries A and D. Thus the data support the hypothesis.

\section{Discussion}

This exploratory study was able, with modifications, to apply in a selection of university libraries Hage and Aiken's methodology for investigating the relationship between certain structural variables and the rate of innovation, and produce results that tend more to support the hypotheses than not. It is difficult to compare the findings because of the different kind of statistical analysis possible. Both studies show anomolies that raise many questions that can be answered only by further research.

One of the most obvious questions is, Why does the index of professional training in the agency study always, contrary to the theory, show a negative relationship with the rate of innovation? In the library study it shows a strong positive relationship for libraries B and $\mathrm{C}$ but not for libraries A and B. One plausible explanation for the association between professional training and the rate of innovation is that because all the library subjects were professionals, there would be higher mean scores. However, this does not account for the differences between the two sets of libraries.

The difference in the two studies of strength of association between the number of occupational specialties and the rate of innovation may be related to a number of factors. These include: (1) more identifiable occupational specialties may exist in health and welfare agencies; (2) the number of specialties reported by agency directors may be inflated; (3) the number of specialties reported by the professional library staff may be deflated. Interviews revealed that many librarians are not accustomed to thinking of themselves as having a specialty. It appears that in the libraries studied the pervasive model for professionals was that of generalists rather than specialists.

The effect on the findings of data collected from a selected $N$ of four is difficult to assess. The methodology did permit the identification of differentiation in the rate of innovation among the four libraries. The spread is 
not great except for library C, which in 1974 records thirteen innovations. This number accounts for over 60 percent of the total of twenty innovations reported in that year. There is no consistent pattern for the annual rate of innovation in any library. The largest total number of innovations-twentythree - is reported for 1973. The empirical data do not provide an explanation for these phenomena nor is this investigator aware of any environmental conditions that would explain them.

It is legitimate to wonder whether budget constraints were affecting the rate of innovation. During the interviews no library director indicated that it had not been possible to implement a planned change because of lack of financial resources. However, all four directors did anticipate increasing difficulty in introducing new services or staff as budget constraints continued, and recognized the possibility of cutting back in some areas in order to be innovative in others.

One of the assumptions made in this study was that the ten years spent by Hage and Aiken in developing and maintaining internal consistency, reliability, and content validity of the core indicators and measures warranted their acceptance. A recent study on the reliability and validity of the indexes used to operationalize centralization and formalization raises some doubt about the indexes of job specificity and job codification. ${ }^{29}$
It therefore seems desirable to investigate these indexes further.

\section{Conclusion}

This study has reported on the first attempt to assess parts of Hage and Aiken's theory and methodology in a library setting. The four hypotheses relating complexity positively and centralization, formalization, and stratification negatively with the rate of innovation are largely supported. The transferability of most of the methodology, but with modifications, is demonstrated. The study provides librarians with empirical data which they have not had before. It is hoped that the findings will alert librarians to possible effects of different structural variables and that structural arrangements are not immutable but open to manipulation to help achieve a library's goals and objectives.

The results cannot be generalized even though one can speculate they may not be atypical of other ARL libraries. Only additional research can provide answers to some of the questions raised. Especially needed are replications; the use of random, large samples; the use of heterogeneous samples; longitudinal studies; the study of relationships incorporating additional variables; and further testing of the reliability and validity of some of the measures. In addition, the theory needs to be reexamined in the light of new findings.

\section{REFERENCES}

1. Robert Presthus, The Organizational Society: An Analysis and Theory (New York: Random, 1962).

2. Richard R. Hall, Organizations: Structure and Process (Englewood Cliffs, N.J.: PrenticeHall, 1972), p.14.

3. Max Weber, "Bureaucracy," in H. H. Gerth and C. Wright Mills, trans., From Max Weber: Essays in Sociology (New York: Oxford Univ. Pr., 1962), p.196-244.

4. Victor Thompson, "Bureaucracy and Innovation," Administrative Science Quarterly 10:1-20 (June 1965).

5. Helen Howard, "The Relationship between Certain Organizational Variables and the Rate of Innovation in Selected University Libraries" (Ph.D. dissertation, Rutgers University, 1977).

6. Jerald Hage and Michael Aiken, "Program Change and Organizational Properties: A
Comparative Analysis," American Journal of Sociology 72:503-9 (March 1967).

7. Jerald Hage and Michael Aiken, Social Change in Complex Organizations (New York: Random, 1970). This is only one of a series of studies published on their research.

8. Jerald Hage, "An Axiomatic Theory of Organizations," Administrative Science Quarterly 10:289-320 (Dec. 1965).

9. Richard R. Hall, "The Concept of Bureaucracy: An Emperical Assessment," American Journal of Sociology 49:32-40 (July 1963).

10. Peter M. Blau, "Formal Organizations: Dimensions of Analysis," American Journal of Sociology 63:58-69 (July 1957).

11. Arnold S. Tannenbaum and Jerald G. Backman, "Structural vs. Individual Effects," American Journal of Sociology 69:585-94 (May 1964).

12. D. S. Pugh and others, "A Conceptual Scheme 
for Organizational Analysis," Administrative Science Quarterly 8:289-319 (Dec. 1963).

13. Tom Burns and G. M. Stalker, The Management of Innovation (London: Tavistock Publications, 1961).

14. Hage and Aiken, "Program Change," p.507.

15. Peter M. Blau and William R. Scott, Formal Organizations (San Francisco: Chandler, 1962), p.51.

16. Arthur M. McAnally and Robert B. Downs, "The Changing Role of Directors of University Libraries," College and Research Libraries 34:103-25 (March 1973).

17. Millicent D. Abell, "The Changing Role of the Academic Librarian: Drift and Mastery," College and Research Libraries 40:154-64 (March 1979).

18. Peter Drucker, Age of Discontinuity (New York: Harper, 1969), p.193.

19. Peter Drucker, Managing in Turbulent Times (New York: Harper, 1980), p.1.

20. Michael Aiken and Jerald Hage, The Relationship between Organizational Factors and the Acceptance of New Rehabilitation Programs in Mental Retardation (Madison: Univ. of Wisconsin Pr., 1968), p.11.
21. Association of Research Libraries, Academic Library Statistics, 1973-1974 (Washington, D.C.: The Association, 1974).

22. Hall, Organizations, p.9.

23. American Library Association, Library Education and Personnel Utilization (Chicago: The Association, 1976).

24. Hage and Aiken, "Program Change," p.507.

25. Michael Aiken and Jerald Hage, "The Organic Organization and Innovation," Sociology 5:64 (Jan. 1971).

26. Thompson, "Bureaucracy and Innovation," p. 2 .

27. Jon L. Pierce and Andre L. Delbecq, “Organization, Structure, Individual Attitudes and Innovation," Academy of Management Review 2:27-37 (Jan. 1977).

28. Kenneth E. Knight, “A Descriptive Model of the Intra-Firm Innovation Process," Journal of Business 40:478-96 (Oct. 1967).

29. Robert D. Dewer, David A. Whetton, and David Boje, "Examination of the Reliability and Validity of the Aiken and Hage Scales of Centralization, Formalization, and Task Routineness," Administrative Science Quarterly 25:120-29 (March 1980). 